\title{
Standarisasi Mutu Ekstrak Etanol Bunga Soka (Ixora coccinea L.)
}

\author{
Cut Yuliana ${ }^{1}$, Ria Ceriana ${ }^{2, *}$, Rini Shafriyani ${ }^{3}$ \\ ${ }^{1}$ Program Studi Farmasi, Sekolah Tinggi Ilmu Kesehatan Asy Syifa, Kota Banda Aceh, Indonesia \\ ${ }^{2}$ Program Studi DIII Farmasi, Akademi Farmasi YPPM Mandiri, Kota Banda Aceh, Indonesia \\ ${ }^{3}$ Program Studi Farmasi, Fakultas Ilmu Kesehatan, Universitas Ubudiyah Indonesia, Kota Banda Aceh, Indonesia \\ Email: cherry4n4@yahoo.com
}

\begin{abstract}
Abstrak-Standarisasi adalah proses penetapan sifat berdasarkan parameter-parameter tertentu untuk mencapai derajat kualitas yang sama. Ekstrak distandarisasi dengan dua parameter yaitu parameter spesifik dan non spesifik. Agar khasiat dan kualitas ekstrak bunga soka ini dapat terjamin, maka perlu dipenuhi suatu standar mutu produk/bahan ekstrak dengan melakukan standarisasi ekstrak. Standarisasi dilakukan agar dapat diperoleh bahan baku yang seragam yang akhirnya dapat menjamin efek farmakologi tanaman tersebut. Standardisasi merupakan proses penjaminan produk akhir (simplisia, ekstrak atau produk herbal) agar mempunyai nilai parameter tertentu yang konstan dan ditetapkan terlebih dahulu. Metode penelitian dengan melakukan pengujian berbagai parameter pada ekstrak yang dimulai dengan determinasi spesies bunga soka, kemudian penghitungan rendemen, pengujian organoleptic, kadar air, senyawa larut air, senyawa larut etanol. Hasil uji kadar air rata-rata adalah 9,54 \% dan masih dalam standar yang diperbolehkan, kadar air dalam sediaan obat termasuk ekstrak tidak boleh melebihi batas $10 \%$. Berdasarkan hasil penetapan kadar sari larut air 20,7 $\%$ dan kadar sari larut etanol 35,5\%. Kadar sari larut etanol lebih tinggi dibandingkan dengan senyawa larut dalam air dengan demikian senyawa semi polar dalam ekstrak lebih tinggi dari senyawa polar.
\end{abstract}

Kata Kunci: Standarisasi; Ekstrak; Bunga Soka; Ixora coccinea L

Abstract- Standardization is the process of determining properties based on certain parameters to achieve the same degree of quality. The extract was standardized with two parameters, namely specific and non-specific parameters. So that the efficacy and quality of this soka flower extract can be guaranteed, it is necessary to meet a quality standard for the product/extract material by standardizing the extract. Standardization is carried out so that uniform raw materials can be obtained which can finally guarantee the pharmacological effects of these plants. Standardization is the process of guaranteeing the final product (simplicia, extract or herbal product) to have certain parameter values that are constant and predetermined. The research method is by testing various parameters on the extract, starting with determining the species of soka flower, then calculating the yield, organoleptic testing, water content, water soluble compounds, ethanol soluble compounds. The average water content test result is $9.54 \%$ and is still within the permissible standard, the water content in medicinal preparations including extracts should not exceed the $10 \%$ limit. Based on the results of determination of water soluble extract content of $20.7 \%$ and ethanol soluble extract content of $35.5 \%$. The ethanol soluble extract content was higher than the water soluble compounds, thus the semi-polar compounds in the extract were higher than the polar compounds.

Keywords: Standardization; Extract; Soka Flower; Ixora coccinea L

\section{PENDAhuluan}

Ixora coccinea L. Umumnya dikenal sebagai 'Jungle geranium', jugadisebut 'Flame of the woods' dalam Ayurveda. Tipe tanaman ini ialah semak dan berbunga keluarga Rubiaceae. Warna bunga bisa bermacam-macam ada yang berwarna merah atau oranye tetapi pada varietas hias ada yang berwarna putih, kuning dan merah muda (Pulipati et al, 2012).

Ekstrak bunga soka dapat menghambat pertumbuhan bakteri E.coli (Almuzaki, 2018) dan Staphylococcus aureus (Munira et al., 2016). Ekstrak bunga soka juga dapat meningkatkan pertumbuhan sel fibroblast walalupun tidak sebaik control positif (Muslimah, 2019). Skrining fitokimia dari ekstrak metanol Ixora coccinea mengungkapkan berbagai senyawa bioaktif diantaranya flavonoid, alkaloid, steroid, saponin dan tannin (Saha et al., 2008). Senyawa tersebut mampu menghambat pertumbuhan bakteri dengan menghambat sintesis dinding sel bakteri, sintesis protein, dan pembentukan senyawa komplesk melawan protein ekstraselular yang menggangu integritas membran sel bakteri (Fatimah et al., 2016).

Flavonoid merupakan kelompok besar produk alami yang tersebar luas pada tanaman tingkat tinggi struktur kimia dasar flavonoid telah digambarkan sebagai C6, C3, C6 yaitu, dua cincin aromatik yang dihubungkan oleh jembatan tiga karbon. flavonoid komponen bioaktif yang dapt meningkatkan reaksi tubuh terhadap senyawa seperti allergen, virus dan karsinogen (Swanson, 2015). Karena manfaat yang terkandung di dalam bunga soka maka bunga soka dibuat dalam bentuk ekstrak.

Ekstraksi merupakan teknik pemisahan secara kimia dengan cara memisahkan atau menarik senyawa-senyawa yang terkandung di dalam sampel (Leba, 2017). Tujuan ekstraksi bahan alam ialah untuk menarik komponen kimia yang terdapat pada bahan alam. Ekstraksi ini didasarkan pada prinsip perpindahan massa komponen zat ke dalam pelarut, dimana perpindahan mulai terjadi pada lapisan antar muka kemudian berdifusi masuk ke dalam pelarut (Najib, 2018 ).

Agar khasiat dan kualitas ekstrak bunga soka ini dapat terjamin, maka perlu dipenuhi suatu standar mutu produk/bahan ekstrak dengan melakukan standarisasi ekstrak. Standarisasi dilakukan agar dapat diperoleh bahan baku yang seragam yang akhirnya dapat menjamin efek farmakologi tanaman tersebut. Standardisasi merupakan proses penjaminan produk akhir (simplisia, ekstrak atau produk herbal) agar mempunyai nilai parameter tertentu yang konstan dan ditetapkan terlebih dahulu. Standarisasi adalah proses penetapan sifat berdasarkan parameter-parameter tertentu untuk mencapai derajat kualitas yang sama. Ekstrak distandarisasi dengan dua parameter yaitu parameter spesifik dan non spesifik pada ekstrak daun jati belanda dan the pelarut (Najib, 2018 ). Standarisasi dilakukan agar mengahasilkan bahan baku yang aman, bermutu dan berkhasiat seperti halnya standarisasi ekstrak daun nona makan sirih (Clerodendrum $x$ 
Journal of Pharmaceutical and Health Research

Vol 3, No 1, Februari 2022, pp. 1-5

ISSN 2721-0715 (media online)

DOI 10.47065/jharma.v3i1.1322

speciosum dombrain) (Ayuanji Halilah et al., 2017), batang kayu kuning (Arcangelisia flava (L.) Merr) (Umayah et al., 2015) dan kayu sanrego (Anam et al., 2013).

\section{METODOLOGI PENELITIAN}

\subsection{Jenis Penelitian}

Jenis penelitian ini adalah eksperimental laboratorium dengan melakukan pengujian.

\subsection{Waktu dan Tempat Penelitian}

Penelitian dilakukan dari bulan Desember 2018 sampai April 2019. Adapun tempat penelitiannya di Laboratorium Mikrobiologi FMIPA Unsyiah untuk pembuatan ekstrak etanol bunga soka, Laboratorium Farmasetika Jurusan Farmasi FMIPA Unsyiah untuk pembuatan sediaan gel dan Laboratorium Farmakologi Institut Atjeh untuk perlakuan hewan coba.

\subsection{Alat dan Bahan}

1. Alat

Alat-alat yang digunakan pada penelitian ini yaitu timbangan analitik, ayakan mesh 65, batang pengaduk, blender, gelas ukur, kertas whatman No.42, oven, rotary vacuum evaporator (Heidolph.v.v 2000), waterbath, magnetik stirer, lumpang dan alu, hot plate, penggaris, jangka sorong, lempeng logam, kaca transparan, kaca bulat, stik pH universal.

2. Bahan

Bahan yang digunakan yaitu Bunga soka, Na-cmc, etanol 96\%.

\subsection{Penyiapan Bahan Tumbuhan}

1. Pengumpulan bahan tumbuhan

Bunga soka diambil di sekitaran Kota Banda Aceh khususnya di daerah Desa Tanjung Selamat Kecamatan Darussalam diambil dalam keadaan segar. Selanjutnya bunga ditimbang sebanyak $500 \mathrm{~g}$.

2. Determinasi Tumbuhan

Determinasi dilakukan untuk menentukan nama atau jenis tumbuhan secara spesifik. Determinasi bertujuan untuk mendapatkan suatu spesies yang tepat sasaran karena dalam pemanfaatannya, tumbuhan memiliki berbagai jenis varietas dan sebagainya.

\subsection{Pembuatan Ekstrak Bunga Soka}

Bunga soka dipilih dan dibersihkan dari kotoran ditimbang sebanyak 500 gram. Bunga selanjutnya dicuci bersih dengan air mengalir agar semua kotoran yang menempel terbuang dari bunga soka. Bunga soka dikering anginkan di atas koran dalam suhu ruangan dan terlindung dari sinar matahari langsung. Simplisia yang sudah kering ditimbang dan siap untuk proses maserasi. Simplisia dimasukkan ke dalam wadah tertutup yang direndam dengan etanol $96 \%$ perbandingan $1: 1$. Lalu ditutup dan disimpan selama 2-3 hari dan sesekali diaduk. Hasil maserasi disaring dan simplisia direndam kembali dengan etanol $96 \%$. Maserat yang diperoleh dari maserasi pertama dan kedua disaring lagi dengan kertas saring. Filtrat yang diperoleh kemudian dipekatkan dengan alat vacuum rotary evaporator suhu $40-50^{\circ} \mathrm{C}$ sehingga akan didapatkan ekstrak kental. Ekstrak dibebas etanolkan dengan cara dipanaskan di atas waterbath. Ekstrak disimpan dalam wadah tertutup dan diletakkan di dalam kulkas.

\subsection{Standarisasi Ekstrak}

1. Uji Organoleptis

Pada pengujian organoleptis dilakukan pengamatan secara langsung seperti bentuk, warna, bau dan pengotor misalnya serangga.

2. Uji Kadar Air

Masukan ekstrak sebanyak 1-2 gram ke dalam wadah yang ditara terlebih dahulu, keringkan pada suhu $105^{\circ} \mathrm{C}$. Bobot ditimbang setiap 30 menit hingga bobot tetap (Depkes RI 2008). Persen kadar air dihitung dengan rumus 1 :

$$
\text { Kadar Air }=\frac{\mathrm{W} 0-\mathrm{Wt}}{\mathrm{Wt}} \mathrm{X} 100 \%
$$

Keterangan :

$\mathrm{Wo}=$ bobot awal $(\mathrm{g})$

$\mathrm{Wt}=$ bobot akhir $(\mathrm{g})$

3. Penetapan kadar senyawa larut etanol

Kadar senyawa larut etanol ditetapkan dengan menimbang 0,5 gram ekstrak bunga soka, kemudian dimasukan ke dalam labu bersumbat dan ditambahkan $10 \mathrm{~mL}$ etanol 96\%. Campuran dikocok berkali-kali selama 6 jam pertama, kemudian dibiarkan selama 18 jam dan disaring, filtrat sebanyak $2 \mathrm{~mL}$ diuapkan hingga kering dalam cawan penguap yang sebelumnya telah dipanaskan pada suhu $105^{\circ} \mathrm{C}$ hingga bobot tetap (Departemen Kesehatan, 2008). Kadar sari larut etanol dihitung dengan persamaan rumus 2 di bawah ini: 
Vol 3, No 1, Februari 2022, pp. 1-5

ISSN 2721-0715 (media online)

DOI 10.47065/jharma.v3i1.1322

$$
\text { Kadar Senyawa Larut Etanol }=\frac{\mathrm{Wt}-\mathrm{W} 0}{\mathrm{We}} \times 100 \%
$$

Keterangan :

Wo = berat c awan konstan $(\mathrm{g})$

$\mathrm{Wt}$ = bobot akhir filtrat + cawan konstan $(\mathrm{g})$

$\mathrm{W}_{\mathrm{e}}=\operatorname{bobot}$ ekstrak $(\mathrm{g})$

4. Penetapan Kadar Senyawa Larut Air

Kadar senyawa larut air ditetapkan dengan menimbang seksama 0,5 g ekstrak bunga soka, kemudian dimasukan ke dalam labu bersumbat dan ditambahkan $10 \mathrm{~m}$ air jenuh kloroform. Campuran dikocok berkali-kali selama jam pertama., kemudian dibiarkan selama 18 jam dan disaring. Filtrat sebanyak $2 \mathrm{~mL}$ diuapkan hingga kering dalam cawan penguap yang sebelumnya telah dipanaskan pada suhu $105^{\circ} \mathrm{C}$ hingga bobot tetap (Departemen Kesehatan, 2008). Kadar sari larut air dihitung dengan persamaan 3 di bawah ini:

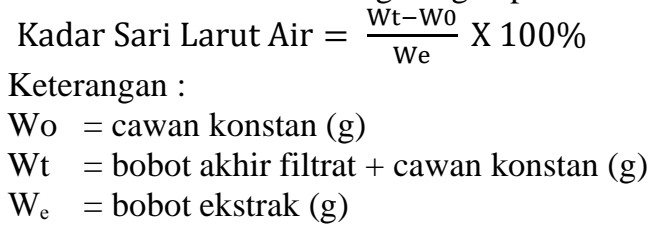

\section{HASIL DAN PEMBAHASAN}

\subsection{Hasil Determinasi Tumbuhan}

Hasil Determinasi tumbuhan yang dilakukan oleh peneliti pada Fakultas Matematika dan ilmu pengetahuan alam, Laboratorium Biokimia Banda Aceh, bahwa tumbuhan yang di gunakan adalah bunga soka (Ixora Coccinea L. ) dengan klasifikasi sebagai berikut: Kingdom : Plantae (Tumbuhan), Sub Regnum/Sub kingdom : Tracheobionta (tumbuhan berpembuluh), Super Divisi: Magnoliophyta (Tumbuhan berbunga ), Kelas: Magnoliopsida (berkeping dua/dikotil), Sub kelas: Asteridae, Ordo:Rubiales, Famili: Rubiaceae, Genus: Ixora L., Spesies:Ixora coccinea L.

\subsection{Ekstraksi Bunga Soka}

Sebanyak 500 gram bunga soka disortasi terlebih dahulu kemudian di kering anginkan pada suhu ruangan selama 3 hari setelah kering ditimbang kembali dan didapatkan berat keringnya sebanyak 300 gram kemudian di maserasi menggunakan pelarut etanol 96\% sebanyak 2 liter selama 3 hari dengan 2 kali maserasi dan sesekali diaduk. Maserasi pertama dan ke dua kemudian digabungkan dan diuapkan menggunakan rotary vacuum evaporator dan di dapatkan ekstrak kental sebanyak 20 gram, hasil rendemen dapat dilihat sebagai berikut:

$$
\begin{aligned}
\text { Rendemen } & =\frac{\text { Berat Ekstrak kental }(\text { gram })}{\text { Berat simplisia }(\text { gram })} \times 100 \% \\
\text { Rendemen } & =\frac{20 \text { gram }}{300 \text { gram }} \times 100 \% \\
\text { Rendemen } & =6,66 \%
\end{aligned}
$$

\subsection{Standarisasi Ekstrak}

1. Uji Organoleptik

Uji orngoleptik pada ekstrak bunga soka merupakan ekstrak kental bewarna coklat kemerahan serta rasa yang kurang sepat serta berbau khas bunga soka.

2. Uji kadar air

Hasil pengujian kadar air dalam ekstak dapat dilihat pada tabel 1. di bawah ini.

Tabel 1. Hasil Pengujian Kadar Air Pada Ekstrak Bunga Soka

\begin{tabular}{cc}
\hline Bobot awal $(\mathrm{Wo})$ & Bobot akhir $(\mathrm{Wt})$ \\
\hline 25,772 & 23,451 \\
25,802 & 23,557 \\
25,792 & 24,529 \\
\hline
\end{tabular}

Berdasarkan hasil uji kadar air rata-rata adalah 9,54 \% dan masih dalam standar yang diperbolehkan, kadar air dalam sediaan obat termasuk ekstrak tidak boleh melebihi batas $10 \%$ (Departemen Kesehatan, 2008). Apabila kadar air melebihi $10 \%$ ekstrak mudah di tumbuhi jamur dan bakteri dapat (Depkes, 1980).

3. Penetapan kadar senyawa larut air

Hasil pengujian di laboratorium untuk kadar senyawa larut air dapat dilihat pada tabel 3.2. 
Journal of Pharmaceutical and Health Research

Vol 3, No 1, Februari 2022, pp. 1-5

ISSN 2721-0715 (media online)

DOI 10.47065/jharma.v3i1.1322

Tabel 2. Hasil Penghitungan Kadar Senyawa Larut Air

\begin{tabular}{ccc}
\hline Cawan konstan $(\mathrm{Wo})$ & Bobot ekstrak $\left(\mathrm{W}_{\mathrm{e}}\right)$ & Bobot akhir filtrate $(\mathrm{Wt})$ \\
\hline 25,336 & 0,526 & 25,533 \\
25,486 & 0,517 & 25,531 \\
25,442 & 0,528 & 25,527 \\
\hline
\end{tabular}

Tujuan penetapan kadar senyawa terlarut dalam air yaitu untuk menunjukan senyawa yang bersifat polar dimana senyawa tersebut memiki kepolaran yang sama dengan air. Ekstrak sampel di larutkan di dalam air kemudian dipanaskan pada suhu $105^{\circ} \mathrm{C}$. senyawa yang tertinggal pada cawan setelah dipanaskan dikatakan senyawa yang larut dalam air. Untuk pelarutan ekstrak digunakan kloroform $10 \mathrm{ml}$ dalam $100 \mathrm{ml}$ akudes fungsi dari kloroform yaitu menarik pengotor dalam ekstrak yang memiliki sifat non polar dan aquadest melarutkan senyawa yang bersifat polar (Rosyidah, 2016).

4. Penetapan Kadar Senyawa Larut Etanol

Hasil penghitungan untuk menetapkan kadar senyawa larut etanol dapat dilihat pada tabel di bawah ini:

Tabel 3. Hasil Penghitungan Kadar Senyawa Larut Etanol

\begin{tabular}{ccc}
\hline Berat cawan $(\mathrm{Wo})$ & Bobot ekstrak $(\mathrm{Wt})$ & Bobot akhir $\left(\mathrm{W}_{\mathrm{e}}\right)$ \\
\hline 25,364 & 0,511 & 25,521 \\
25,478 & 0,520 & 25,674 \\
25,551 & 0,535 & 25,744 \\
\hline
\end{tabular}

Penetapan kadar sari larut etanol untuk menunjukan senyawa yang bersifat semi polar dimana sifat kepolaran senyawa tersebut sama dengan etanol. Pelarut yang digunakan pada ekstrak etanol $96 \%$ dan dipanaskan pada suhu $105^{\circ} \mathrm{C}$. senyawa yang tertinggal setelah pemanasan dikatakan senyawa yang larut dalam etanol (Rosyidah, 2016).

\section{KESIMPULAN}

Hasil uji kadar air rata-rata adalah 9,54\% dan masih dalam standar yang diperbolehkan, kadar air dalam sediaan obat termasuk ekstrak tidak boleh melebihi batas $10 \%$. Berdasarkan hasil penetapan kadar sari larut air 20,7 \% dan kadar sari larut etanol 35,5\% kadar sari larut etanol lebih tinggi dibandingkan dengan senyawa larut dalam air dengan demikian senyawa semi polar dalam ekstrak lebih tinggi dari senyawa polar.

\section{DAFTAR PUSTAKA}

ALMUZAKI, Z. (2018). POTENSI ANTIBAKTERI EKSTRAK BUNGA SOKA (Ixora coccinea, L) TERHADPA PERTUMBUHAN BAKTERI Escherichia coli. http://repository.stikes-bth.ac.id/663/

Anam, S., Yusran, M., Trisakti, A., Ibrahim, N., Khumaidi, A., \& Sulaiman Zubair, M. (2013). Standarisasi Ekstrak Etil Asetat Kayu Sanrego (Lunasia amara Blanco). Bestjournal.Untad.Ac.Id, $\quad 2(3), \quad$ https://bestjournal.untad.ac.id/index.php/ejurnalfmipa/article/view/1861

Ayuanji Halilah, N., Febrina, L., Ramadhan Laboratorium Penelitian dan Pengembangan Kefarmasian, A. M., \& Tropis, F. (2017). Standarisasi Ekstrak Daun Nona Makan Sirih (Clerodendrum x speciosum Dombrain). Prosiding.Farmasi.Unmul.Ac.Id, 7-8. https://doi.org/10.25026/mpc.v6i1.xxx

Ekstraksi Senyawa Bahan Alam - Ahmad Najib - Google Buku. (n.d.). Retrieved February 27, 2022, from https://books.google.co.id/books?hl=id\&lr=\&id=ad2CDwAAQBAJ\&oi=fnd\&pg=PR5\&dq=Najib,+A.+(2018).+Ekstraksi+sen yawa+bahan+alam.+Deepublish.\&ots=154whVGyIG\&sig=76ApzG6eD8Xbrn9kqhmGD3JWQGg\&redir_esc=y\#v=onepage\&q =Najib\%2C A. (2018). Ekstraksi senyawa bahan alam. Deepublish.\&f=false

Farmakope Herbal Indonesia. Jakarta: Departemen Kesehatan... - Google Cendekia. (n.d.). Retrieved February 28, 2022, from https://scholar.google.com/scholar?hl=id\&as_sdt=0,5\&q=Farmakope+Herbal+Indonesia.+Jakarta:+Departemen+Kesehatan+R epublik+Indonesia,

Fatimah, S., Nadifah, F., Burhanudin, I., Studi, P. D., Kesehatan STIKES Guna Bangsa Yogyakarta J1 Ring Road Utara, A., \& Istimewa Yogyakarta, D. (2016). Uji daya hambat ekstrak etanol kubis (Brassica oleracea var. capitata f. alba) terhadap bakteri Staphylococcus aureus secara in vitro. Journal3.Uin-Alauddin.Ac.Id, 4(2), 102-106. https://doi.org/10.24252/bio.v4i2.2515

Leba, M. (2017). Buku Ajar: Ekstraksi dan real kromatografi. https://books.google.com/books?hl=id\&lr=\&id=x1pHDwAAQBAJ\&oi=fnd\&pg=PA52\&dq=Leba,+M.+A.+U.+(2017).+Buku +Ajar:+Ekstraksi+dan+real+kromatografi.+Deepublish.\&ots=TIbcy8bz2N\&sig=6uJl_i9Q54wZPGqpa1Zmr50Ma9I

Munira, M., Maisarah, R., \& Nasir, M. (2016). Potensi Antibakteri Ekstrak Bunga Soka (Ixora coccinea L) terhadap Staphylococcus aureus dan Escherichia coli. AcTion: Aceh Nutrition Journal, 1(2), 130. https://doi.org/10.30867/action.v1i2.23

MUSLIMAH, D. (2019). PENGARUH KONSENTRASI EKSTRAK BUNGA SOKA MERAH (Ixora coccinea L) TERHADAP JUMLAH SEL FIBROBLAS DALAM PENYEMBUHAN LUKA SOKET. http://etd.repository.ugm.ac.id/penelitian/detail/167917

Pulipati, S., \& et al. (2012). Evaluation of Antibacterial Activity of Flower Extracts of Ixora coccinea Linn. The Indian Pharmacist, 53-55.

https://www.researchgate.net/publication/270157811_Evaluation_of_Antibacterial_Activity_of_Flower_Extracts_of_Ixora_coc cinea_Linn

Rosyidah, H. (2016). Standardisasi ekstrak Etil asetat Anting-anting (Acalypha indica Linn.) sebagai herba antimalaria. http://etheses.uin-malang.ac.id/id/eprint/5602

Saha, M. R., Alam, M. A., Akter, R., \& Jahangir, R. (2008). In vitro free radical scavenging activity of Ixora coccinea L. Bangladesh 


\section{Journal of Pharmaceutical and Health Research}

Vol 3, No 1, Februari 2022, pp. 1-5

ISSN 2721-0715 (media online)

DOI 10.47065/jharma.v3i1.1322

Journal of Pharmacology, 3(2). https://doi.org/10.3329/bjp.v3i2.838

Swanson, H. (2015). Flavonoids,

inflammation

and

cancer.

https://books.google.com/books?hl=id\&lr=\&id=QdyiCgAAQBAJ\&oi=fnd\&pg=PR5\&dq=Swanson+Hollie.+(2016).+Flavonoi $\mathrm{d}+$ :+inflammation+and+cancer.+British+library+cataloguing+in-publication+data\&ots=Z5rIvO2L4\&sig=ET2kQsqbqEtNgp1KsG7muuDX_jg

Umayah, E., Dan, U., \& Rachmawati, E. (2015). Standarisasi Ekstrak Batang Kayu Kuning (Arcangelisia flava (L.) Merr). https://repository.unej.ac.id/handle/123456789/72668 